\title{
Patterns of Floral Bud Development in Canes of Erect and Trailing Blackberries
}

\author{
Fumiomi Takeda ${ }^{1}$ \\ U.S. Department of Agriculture, Agricultural Research Service, Appalachian Fruit Research Station, 45 \\ Wiltshire Road, Kearneysville, WV 25430
}

\begin{abstract}
Bernadine C. Strik and Derek Peacock ${ }^{2}$
Department of Horticulture, 4017 Agriculture and Life Science Building, Oregon State University, Corvallis, OR 97331
\end{abstract}

\author{
John R. Clark \\ Department of Horticulture, 316 Plant Science Building, University of Arkansas, Fayetteville, AR 72701
}

ADDITIONAL INDEX wORDS. floral primordia, floricane, inflorescence, microscopy, Rubus

\begin{abstract}
Flower bud development was studied in 'Cherokee', 'Boysen', and 'Marion' blackberries (Rubus subgenus Rubus Watson). In 'Cherokee' (erect type), the transition to reproductive development in buds on the branch canes occurred during September in Arkansas and Oregon. Transitions of buds in the axils of the most basal nodes (proximal to the main cane) and the most distal nodes lagged behind buds in the midsection (about nodes 6 to 10). Along the midsection of branch canes, the buds developed uniformly. In buds of 'Boysen' and 'Marion' (trailing type), the transition to reproductive development occurred in October and sepal primordia were observed in most buds examined by November. Progression of floral bud development continued into January, but at a slower rate than in autumn. Buds on the main canes ( $>3 \mathrm{~m}$ long) of 'Boysen' and 'Marion' remained at a more advanced stage of flower bud differentiation than buds on the basal branch canes. In both cultivars, buds from the middle one-third section, and sometimes buds from the bottom one-third section, tended to be more advanced than those buds in the top one-third section during much of the sampling period. The results suggest that rate and patterns of flower bud development vary among cultivars grown in different locations. However, the pattern of flower bud development was not in a basipetal fashion on main or branch canes.
\end{abstract}

Blackberry (Rubus subgenus Rubus Watson) cultivars of North America originated from the interbreeding of many genetically heterogeneous and morphologically variable species (Moore and Skirvin, 1990). Cultivars differ greatly in fruit and plant growth habit and are classified as erect, western trailing, and semierect, based on gross morphology (Crandall, 1995). While some blackberries are well adapted to a specific region of the United States, others have become commercially important in several, distinct climatic and geographic regions. Weather, specifically low winter temperatures, limits where blackberries can be grown. In general, erect and semierect blackberries can survive much lower winter temperatures (less than $-15^{\circ} \mathrm{C}$ ) than trailing types. The western trailing blackberries (e.g., 'Boysen' and 'Marion') are grown mainly in Oregon and California. The primocanes of trailing types are not pruned and the main canes and basal branch canes (natural branches that originate near the base of the main cane) generally grow more than $3 \mathrm{~m}$. In alternate-year systems (Strik, 1992), canes are bundled when they are about $1 \mathrm{~m}$ long in early summer of the off year. Tying or bundling continues until canes are long enough to wrap around two wires at $\approx 1.4$ and $1.8 \mathrm{~m}$ height on trellis posts. Plants fruit the following year. Erect, thorny (e.g., 'Cherokee') blackberries from the University of Arkansas, in contrast, can be grown throughout the temperate zone from the southern United States, to the mid-Atlantic coast region and the Pacific Northwest. Some of the cultivars from this breeding

Received for publication 22 Jan. 2002. Accepted for publication 24 Sept. 2002. We acknowledge the assistance of John Phillips for nonparametric statistical analysis of the data. Kenda Woodburn and Dan Chapman in Arkansas and Gloria Murray in Oregon provided assistance in material handling. James Carew and Thomas Tworkoski provided a critical review of an earlier draft of this manuscript. Ann K. Hummell prepared the graphics.

${ }^{1}$ To whom correspondence should be addressed:e-mail ftakeda@ afrs.ars.usda.gov. ${ }^{2}$ Current address: R\&D Department, Enfield Farms, Inc., Lynden, WA 98264. program are grown in the highlands of Central America (J.R. Clark, personal communication). Blackberries with an erect or semierect growth are typically summer pruned by topping the primocanes at $\approx 1.5$ to $2 \mathrm{~m}$ height. Branch canes are shortened to $\approx 30$ to $50 \mathrm{~cm}$ in the dormant season (Patterson, 1992; Strik, 1992).

Phenology and biology of flowering in cultivated and wild raspberries and blackberries have been studied under diverse environmental conditions in the United Kingdom (Robertson, 1957; Williams, 1959), and in the United States in Arkansas (Takeda et al., 2002), Maryland (Waldo, 1933), Missouri (Warmund and George, 1990), Oregon (Waldo, 1933; Takeda et al., 2002), and West Virginia (Takeda and Wisniewski, 1989; Takeda et al., 2002; Warmund et al., 1992). Under temperate-zone growing conditions, biennial-fruiting raspberries and blackberries have a clearly defined seasonal pattern of dormancy, entering the endodormant phase as a result of shortened photoperiod and low and moderate temperatures in autumn, and exiting after sufficient winter cold (Carew et al., 2000; Moore and Caldwell, 1985). Blackberries grow into the late autumn and the canes do not form a conspicuous terminal rosette of leaves, as is the case in red raspberries ( $R$. ideaus L.). Cane growth is likely to be stopped by either decreasing temperatures or rooting at the tips if the canes are in contact with the ground (Crandall, 1995).

Generally, short days and cool temperatures cause flower bud initiation in red raspberries (Williams, 1959). Among the blackberries, floral initiation occurred as early as September in 'Eldorado' and a wild blackberry ( $R$. canadensis L.) in Maryland (Waldo, 1933), in 'Austin Thornless', 'Loganberry', 'Mommoth', and a wild, trailing blackberry ( $R$. macropetalus Dougl.) in October in Oregon (Waldo, 1933), and in spring in 'Darrow' and 'Himalaya Giant' in Missouri (Warmund et al., 1988). In West Virginia, flower bud initiation occurred in the fall in 'Black Satin' and in the spring in 'Hull Thornless' (Takeda and Wisniewski, 1989; Warmund et al., 
1992). The time of flower initiation can vary significantly with location. For example, the primocane-fruiting 'Lloyd George' red raspberry initiated flowers in July in Nottingham, U.K. (Williams, 1959) but not until late August in Dundee, U.K. (Robertson, 1957). Also, certain cultural practices, such as withholding of water and applications of plant growth regulators, can affect the time of flower bud initiation and rate of early flower bud development in red raspberries (Crandall and Chamberlain, 1982). Postharvest stresses during the critical stages of flower development can have an adverse effect on flower quality to the extent that the next season's crop yield may be reduced (Crandall, 1995).

Little is known about the flower bud development in blackberry cultivars of commercial importance in Oregon and Arkansas. The onset, progression, and completion of reproductive development appear to be highly variable among blackberry cultivars and apparently are influenced, in part, by prevailing environmental (e.g., temperature) and some internal factors. Waldo (1933) noted that little or no flower bud development occurred between December and March in Maryland. Recently we described the progression of flower bud development in four blackberry cultivars in association with prevailing winter temperatures at several locations (Takeda et al., 2002). A better understanding of sexual reproduction in blackberries is important in research as well as in management of this crop, e.g., utility of new primocane-fruiting germplasm materials and protected environment cropping systems. Our objective was to study the pattern of flower bud differentiation 1) along the length of main and basal branch canes in 'Boysen' and 'Marion' blackberries growing in Oregon and 2) during the early phases of bud development in branch canes of 'Cherokee' blackberry growing in Arkansas and Oregon.

\section{Materials and Methods}

Blackberry Cultivars, COllection Sites, AND SEASONS. Bud samples of 'Boysen' and 'Marion' blackberries were collected at Oregon State University, North Willamette Research and Extension Center (NWREC), Aurora, Ore., during the 1995-96 and 1996-97 growing seasons from September to March at 3- to 4-week intervals. Buds of 'Cherokee' blackberry were collected at 2- to 3-week intervals during August to October 2001, from a grower's field near Hillsboro, Ore. (35 km from NWREC), and at the University of Arkansas Fruit Substation, Clarksville, Ark. For this study, the examination of 'Cherokee' buds ended after 3 months of sampling because we (Takeda et al., 2002) previously reported that the differentiation of flower buds in 'Cherokee' had already occurred by October.

Plant material: 'Cherokee'. Six untrimmed branch canes located at 0.9 to $1.5 \mathrm{~m}$ high and several branch canes from 0 to 0.6 m height were collected from 11-year-old and 21-year-old (in 2001) 'Cherokee' plants growing near Hillsboro and Clarksville, respectively. For each branch cane (typically 1.0 to $1.3 \mathrm{~m} \mathrm{long}$ ), the bud node position of axillary buds was counted from the base of the branch. The buds were then excised from canes and killed in a fixative. Plants in Arkansas were grown in rows set $3.7 \mathrm{~m}$ apart using standard blackberry production practices for the midsouthern states, such as annual applications $\left(\mathrm{kg} \cdot \mathrm{ha}^{-1}\right)$ of $\mathrm{N}(50), \mathrm{P}(21.7)$, and $\mathrm{K}$ (41.5), chemical weed control, spring application of liquid lime sulfur for anthracnose control, summer topping of primocanes, dormant-season removal of floricanes, and overhead sprinkler irrigation on an as needed basis in the summer (Patterson, 1992). In Oregon, 'Cherokee' plants were spaced at $0.9 \times 3$ m and were trained to a temporary $\mathrm{T}$ trellis (cross-arm at about $1 \mathrm{~m}$ high). All the types of blackberries sampled in Oregon ('Cherokee' and the two described below) were grown according to standard commercial practice (Crandall, 1995). Plants received annual fertilizer applications $\left(\mathrm{kg} \cdot \mathrm{ha}^{-1}\right.$ ) of $\mathrm{N}(45), \mathrm{P}(19.6)$, and $\mathrm{K}$ (37.4) in April and additional N (25), P (10.9), and K (20.8) in late May. Supplemental overhead irrigation was provided weekly at a rate of $3 \mathrm{~cm}$ as needed from June to September.

Plant material: 'Boysen' And 'Marion'. In Oregon, a sample of 10 to 20 axillary buds from main and branch canes in the top $(>2$ $\mathrm{m})$, middle (1 to $2 \mathrm{~m}$ ), and bottom ( 0 to $1 \mathrm{~m}$ ) portions of three floricanes of 'Boysen' and 'Marion' blackberry plants was processed on each collection date. These trailing blackberry cultivars were 9 years old (in 1995) and were grown in the alternate-year production system at a $2.4 \times 3 \mathrm{~m}$ spacing for 'Marion' and at a 1.8 $\times 3 \mathrm{~m}$ spacing for 'Boysen' at NWREC. Plants were sampled following an off year of only primocane growth (Strik, 1992).

DisSECTION AND BUD ASSESSMENT. Bud dissections were carried out to determine the stage of bud development under a stereoscope (model SMZ-U; Nikon). Bud scales were excised with a scalpel to reveal the apical meristem. Exposed apices were examined under $\approx 10$ to $70 \times$ magnifications to quantify the developmental stages of each bud, based on a numerical rating system of 1 to 10 (Table 1). Buds that were obviously necrotic were not rated.

Statistical analysis. The bud rating values for the various nodes were subjected to a nonparametric analysis of variance (Kruskal-Wallis test) to determine significant differences due to node position and cane section using a SAS (SAS Institute Inc., Cary, N.C.) statistical package. A Kruskal-Wallis test was used because the various levels for the scale used to rate bud development were not necessarily equally spaced and did not conform to the assumption used in traditional (or parametric) analysis of variance. Otherwise indicated, multiple comparisons were performed using a

Table 1. Description and numerical value for stages of bud development in blackberry. ${ }^{\mathrm{z}}$

\begin{tabular}{ll}
\hline \hline Stage & Description \\
\hline 1 & Buds in vegetative phase with leaf primordia encircling the flat apical meristem. \\
2 & Inflorescence axis beginning to develop with a few leaf, phyllome, and bract primordia evident \\
3 & Terminal flower of inflorescence is differentiated. The apex is enlarged and sepal initiation is evident on the shoulder of apex. \\
4 & Terminal flower of inflorescence is developed. Sepal primordia enlarge and become three-lobed. \\
5 & Petal primordia are differentiated. The central receptacle (torus) in the terminal flower is enlarged. Sepals fuse and enclose central receptacle. \\
6 & Receptacle of terminal flower elongates and becomes dome-shaped. Petal primordia are enlarged. Sepals and petals are in alternate arrangements. \\
7 & Stamen primordia are differentiated on floral cup. \\
8 & Gynoecial structures are noticeable on the bottom half of dome-shaped receptacle. \\
9 & Gynoecia cover much of central receptacle. Petals expand and enclose stamens and receptacle. \\
10 & Anther sacs and stamen filaments are developed and style and stigma are evident on pistil primordia.
\end{tabular}

${ }^{\mathrm{z} A f t e r ~ T a k e d a ~ a n d ~ W i s n i e w s k i, ~} 1989$. 


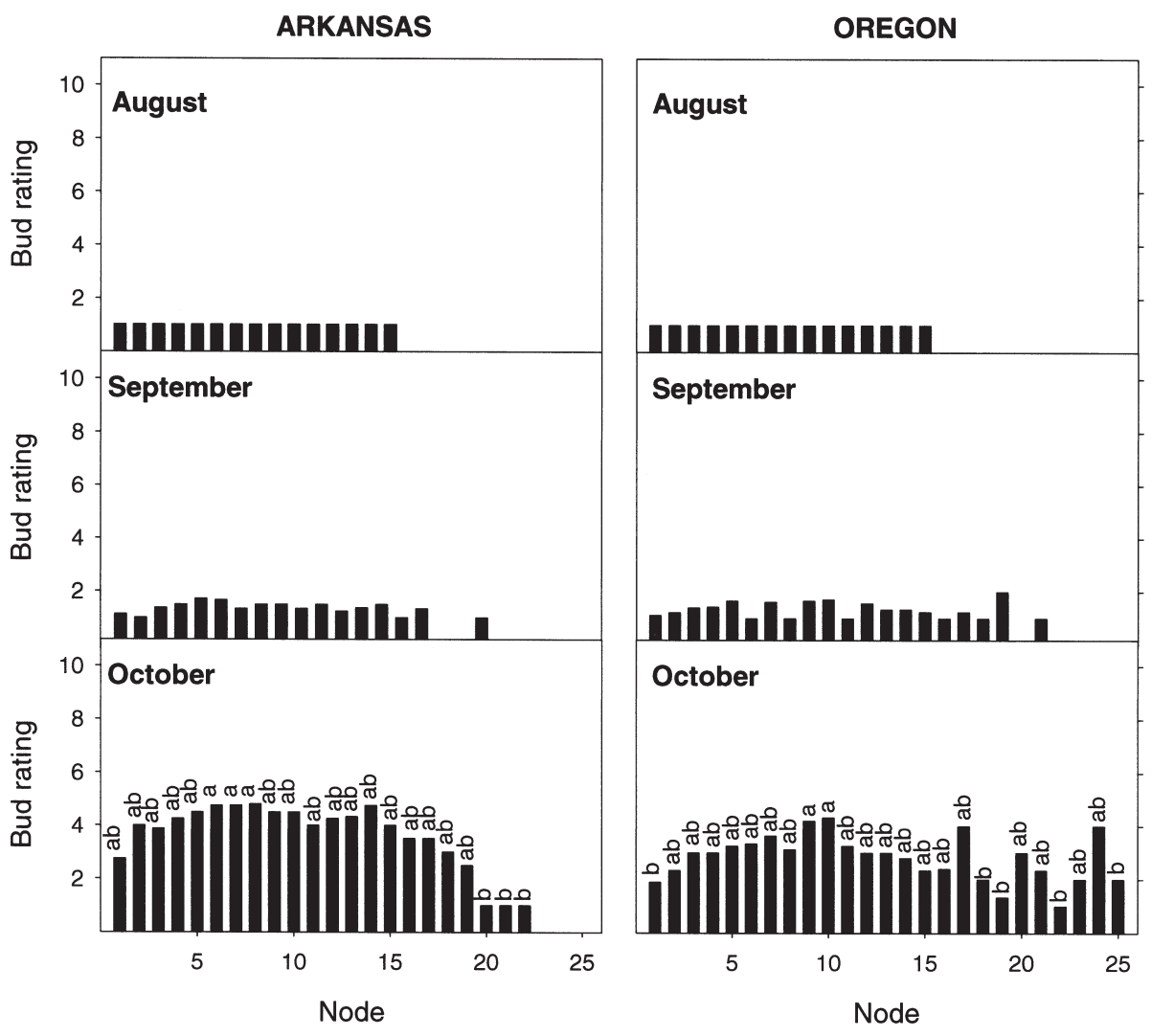

Fig. 1. Early stages of flower bud development in branch canes of 'Cherokee'. The relationship between reproductive development and node position (1 being most proximal to the main cane) along the length of untrimmed lateral branches is shown for buds collected at Clarksville, Ark. (left), and Hillsboro, Ore. (right). Buds were examined on branches collected in August, September, and October 2001 and rated for stage of reproductive development using the rating scale described in Table 1. Note that all the buds sampled in August were at stage 1 (no variance). In September, the bud position had no effect on flower bud development in Arkansas $(P=0.395)$ or Oregon $(P=0.305)$. For October bud rating values, means were separated by Duncan's multiple range test, $P \leq 0.10$.

very conservative procedure similar to Bonferroni LSD (Dunn, 1964) for unequal sample sizes, $P \leq 0.10$.

\section{Results and Discussion}

The morphological progress of flower bud differentiation in 'Cherokee', 'Boysen', and 'Marion' blackberries was similar to that of other blackberry cultivars. The descriptions of changes in the size and shape of the bud apices and organogenesis are provided elsewhere (Takeda et al., 2002; Takeda and Wisniewski, 1989). Therefore, the results presented herein emphasize the pattern of bud development along the length of untrimmed branch canes of 'Cherokee' and main and branch canes of 'Boysen' and 'Marion'.

In untrimmed branch canes of 'Cherokee', the progression of bud differentiation was not uniform along the branch length (Fig. 1). In August, all buds from Arkansas and Oregon were still vegetative. However, in September, numerous axillary buds located at nodes 5 through $\approx 14$ exhibited the development of an inflorescence axis (Stage 2), while the smaller axillary buds at the basal one to two nodes and buds near the distal end of the lateral branch were still vegetative (Stage 1). By October, the buds in the middle section of the branch cane had advanced further as sepals and, occasionally, petal primordia developed on the shoulder of the terminal flower of the inflorescence while the buds at nodes 1 to 3 and at the most distal positions on the lateral branch exhibited only early stages of inflorescence axis development. Nonparametric mean separation of bud ratings in October failed to show any differences ( $p=0.065$ and 0.054 for Arkansas and Oregon, respectively), but it is a very conservative procedure, similar to Bonferroni LSD (Dunn, 1964). WhenDuncan's multiple range test $(P<0.10)$ was applied to the rankings for 'Cherokee' buds samples from Arkansas, buds at nodes 6, 7, and 8 were more advanced than those at nodes 20,21, and 22. For 'Cherokee' samples from Oregon, the buds at nodes 9 and 10 were significantly more advanced than those buds at nodes 1,19 , 22, 25, and 26. Previously we had reported that bud development within summer-hedged branch canes, in which only those buds from the middle and basal sections were examined, was rather uniform and not affected by node position (Takeda et al., 2002). The results of this study (Fig. 1) indicated, as was the case in 1995-96 and 1996-97 seasons, that flower initiation in 'Cherokee' blackberry first became apparent at the bud apex with an increase in meristem size during September in Arkansas and Oregon and the early developmental activity proceeded similarly at both locations (Takeda et al., 2002).

In late summer or early autumn, the size of the 'Cherokee' axillary bud is not a good indicator of its readiness to become reproductive (data not presented). For example, measurements of axillary bud size along the midsection of $\approx 1 \mathrm{~m}$ long branch canes taken in September 2001, indicated that the average length of buds at node 4 was $6 \pm 1.0 \mathrm{~mm}$, gradually decreasing to $2 \pm 0.5 \mathrm{~mm}$ at node 20. At the distal end, small leaves subtended the buds. Buds at the basal two or three nodes were about $4 \pm 0.4 \mathrm{~mm}$ in length and sometimes there was no subtending leaf. It is not uncommon to have bud scales that are shed early in shoot elongation subtend the basal buds rather than a true leaf. In contrast, all the buds in the midsection of branch canes were subtended by an expanded, trifoliate leaf and reached a certain physiological state essential for making the transition to reproductive development rather uniformly (Fig. 1) despite a 3-fold difference in bud size. We observed that in October the buds on branch canes from the terminus of summer-topped main canes were more advanced than those buds on branch canes near the ground. While buds on branches from more distal nodes were already at stage 4 , many buds on branch canes from the lower portion of the main cane were still at stage 2 (data not presented). Waldo (1933) observed that in red raspberries, flower bud formation begins in buds at the terminal end of a cane and progresses downward. It is possible that this delay in reproductive development in branches close to the ground was a result of apical dominance by growing points more distal to them. Field observations indicated that the lower branch canes of blackberries in hedgerows were shaded by the higher growth and their leaves abscised earlier than the leaves on branch canes more distal on the main cane. Further investigation is warranted to determine if there is a causal relationship between carbohydrate accumulation and flower bud development in blackberries.

Variations in the extent of bud development among blackberry 
cultivars in a given location have been reported (Takeda et al., 2002; Takeda and Wisniewski, 1989; Waldo, 1933). The results of our earlier study (Takeda et al., 2002) clearly demonstrated that temperature plays a major role in determining the extent of bud differentiation. In this study, the monthly scores from the 1995-96 and 1996-97 seasons for both 'Boysen' and 'Marion' were similar ( $t$ test at 5\%). Compilations of meteorological information from Aurora, Ore., indicated that the monthly average maximum, mean, and minimum temperatures from late summer to spring were similar for the two growing seasons the buds were examined (Takeda et al., 2002). Therefore, the data from the two seasons were pooled.

Axillary buds of 'Boysen' and 'Marion' in Oregon exhibited a broadened apical meristem (Stage 3) in November (Tables 2 and 3). There was considerable bud development in both cultivars by December that continued throughout the winter. Buds of 'Boysen' were at a more advanced stage of development than those of 'Marion' entering into winter(Takeda et al., 2002). In both cultivars, bud development along the length of canes was not uniform, but there was clear indication that bud development in main canes was more advanced than in basal branch canes in the early part of bud development. In particular, 'Marion' buds at the middle one-third section of the main and basal branch canes appeared to have been initiated earlier than those buds in the terminal one-third section (Table 3).

Unfortunately, all the floricane samples of 'Boysen' and 'Marion' collected in February and March lacked basal branch canes and comparisons of bud development in main and branch canes could not be made for these 2 months. During winter, bud development in the main branch continued more rapidly in the basal and middle section (Tables 2 and 3). By March, buds in the basal and middle one-third section had terminal flower buds with numerous carpel primordia on the torus (enlarged central receptacle) (Stages 8 and 9). The buds in the distal one-third portion had the apical meristem at the stage where only sepal and petal primordia were differentiated and the central receptacle was just beginning to enlarge, but the gynoecial structures had not differentiated (Stage 6). These findings are similar to those reported by Stanley et al. (1999), who found a greater percentage of buds in the midsections of main canes with a differentiated king flower by late winter than buds in either the basal or distal ends of 'Boysen' canes in New Zealand.

The blackberry has a clearly defined growth cycle (Carew et al., 2000; Moore and Skirvin, 1990). In biennial-fruiting cultivars such as the ones investigated here, vegetative growth occurs in the first year (primocane). The vegetative shoots grow vigorously in length and buds develop in the leaf axils. The primocane exhibits strong apical dominance since only a few lateral branches develop from leaf axils. Lateral branching is typically promoted by removal (topping) (Patterson, 1992; Strik, 1992) or bending of primocanes (Takeda and Peterson, 1999). Early in primocane development, the axillary buds are clearly vegetative as they have potential to develop into a lateral branch (Takeda et al., 2002). In late summer or fall when shoot extension growth is diminished, an irreversible process termed flower induction occurs in the axillary buds, whereby some parts of the meristem are programmed to form flowers (Bernier et al., 1981).

The fact that primocane emergence and shoot extension in blackberries occur over a long period of time (Takeda, unpublished

Table 2. Stage of development in primary axillary buds of 'Boysen' grown in Oregon. Buds were sampled from the distal 1/3, middle 1/3, and basal 1/3 sections of main and basal branch canes, where present, from October to March during 1996-97 and 1997-98 season. Means presented are the averages of two seasons. Refer to Table 1 for description of developmental stages.

\begin{tabular}{|c|c|c|c|c|c|c|c|}
\hline \multirow{2}{*}{$\begin{array}{l}\text { Cane } \\
\text { section }\end{array}$} & \multirow{2}{*}{$\begin{array}{l}\text { Cane } \\
\text { type }\end{array}$} & \multicolumn{6}{|c|}{ Stage of development } \\
\hline & & Oct. & Nov. & Dec. & Jan. & Feb. & Mar. \\
\hline \multirow[t]{2}{*}{ Distal } & Main & $1.3 \mathrm{a}^{\mathrm{z}}$ & $4.7 \mathrm{a}$ & $6.1 \mathrm{a}$ & $5.6 \mathrm{a}$ & 6.6 & 7.3 \\
\hline & Branch & $1.2 \mathrm{a}$ & $2.0 \mathrm{~b}$ & $4.7 \mathrm{a}$ & $2.0 \mathrm{~b}$ & $\mathrm{ND}^{\mathrm{y}}$ & ND \\
\hline \multirow[t]{2}{*}{ Middle } & Main & $2.3 \mathrm{a}$ & $5.3 \mathrm{a}$ & 7.5 & $6.6 \mathrm{a}$ & 8.7 & 9.6 \\
\hline & Branch & $1.6 \mathrm{a}$ & $3.1 \mathrm{~b}$ & $--{ }^{x}$ & $6.4 \mathrm{a}$ & ND & ND \\
\hline \multirow[t]{2}{*}{ Basal } & Main & $2.3 \mathrm{a}$ & $4.9 \mathrm{a}$ & $6.3 \mathrm{a}$ & $6.6 \mathrm{a}$ & 6.1 & 7.3 \\
\hline & Branch & $1.0 \mathrm{~b}$ & $4.9 \mathrm{ab}$ & $6.3 \mathrm{a}$ & $6.4 \mathrm{a}$ & ND & ND \\
\hline
\end{tabular}

${ }^{\mathrm{z}}$ Mean separation within columns within cane type and cane section by a Dunn test, $P \leq 0.10$.

${ }^{y}$ ND indicates that all three floricanes sampled in February and March of 1996 and 1997 lacked a basal branch cane so only the data from the main canes are shown for each cane section.

${ }^{x}$ No buds examined. All buds in the particular section were rubbed off or their stage of bud development could not be determined because floral primordia were damaged excessively.

Table 3. Stage of development in primary axillary buds of 'Marion' grown in Oregon. Buds were sampled from the distal 1/3, middle 1/3, and basal 1/3 sections of main and basal branch canes from October to March during 1996-97 and 1997-98 season. Means presented are the averages of two seasons. Refer to Table 1 for description of developmental stages.

\begin{tabular}{|c|c|c|c|c|c|c|c|}
\hline \multirow{2}{*}{$\begin{array}{l}\text { Cane } \\
\text { section }\end{array}$} & \multirow{2}{*}{$\begin{array}{l}\text { Cane } \\
\text { type }\end{array}$} & \multicolumn{6}{|c|}{ Stage of development } \\
\hline & & Oct. & Nov. & Dec. & Jan. & Feb. & Mar. \\
\hline \multirow[t]{2}{*}{ Distal } & Main & $2.0 \mathrm{a}^{\mathrm{z}}$ & $3.1 \mathrm{a}$ & $4.1 \mathrm{a}$ & 4.0 & 6.1 & 4.3 \\
\hline & Lateral & $1.9 \mathrm{a}$ & $2.5 \mathrm{a}$ & $5.0 \mathrm{a}$ & $--^{x}$ & $\mathrm{ND}^{\mathrm{y}}$ & ND \\
\hline \multirow[t]{2}{*}{ Middle } & Main & 2.2 & $3.6 \mathrm{a}$ & 6.1 & $6.8 \mathrm{a}$ & 7.4 & 9.7 \\
\hline & Lateral & $---^{x}$ & $3.0 \mathrm{a}$ & $--{ }^{x}$ & $5.2 \mathrm{a}$ & ND & ND \\
\hline \multirow[t]{2}{*}{ Basal } & Main & $2.1 \mathrm{a}$ & $2.9 \mathrm{a}$ & $4.8 \mathrm{a}$ & $7.0 \mathrm{a}$ & 7.6 & 8.4 \\
\hline & Lateral & $1.4 \mathrm{a}$ & $2.3 \mathrm{a}$ & $5.3 \mathrm{a}$ & $6.4 \mathrm{a}$ & ND & ND \\
\hline
\end{tabular}

${ }^{\mathrm{z}}$ Mean separation within columns within cane type and cane section by a Dunn test, $P \leq 0.10$.

yND indicates that all three floricanes sampled in February and March of 1996 and 1997 lacked a basal lateral branch so there are no data (nd) for distal, middle, and basal cane sections of branch canes.

${ }^{\mathrm{x}}$ Buds were either rubbed off or their stage of bud development could not be determined because floral primordia were damaged excessively. 
data) may explain, in part, these large variations in the development of individual axillary buds on long, untrimmed canes. Larger sample sizes, the use of cane emergence dates as covariates, and increased frequencies of sampling may help define the relative importance of geographical locations, daylengths, and temperatures as related to the timing of bud development. In this study, a relationship between stages of flower bud development and calendar dates was developed for three cultivars. In future studies, other measurements of elapsed time, e.g., temperature patterns and phenological observations, should be used as well to elaborate on the timing of bud development. In a recent study on floral initiation and organogenesis in almond [Prunus dulcis (Mill. D.A. Webb], Lamp et al. (2001) reported that variations in the timing of developmental events among buds within a tree was extensive and sometimes progress of all the buds on a tree through a given stage of development was greater than the time required for individual buds to move through developmental stages.

At any given time, there were highly variable populations of buds on individual canes and among canes on a plant (Fig. 1, Tables 2 and $3)$. However, we have clearly established in both the erect and trailing blackberries that the pattern of flower bud development does not occur in a basipetal fashion as is the case with the red raspberry. Rather, flower bud differentiation is first observed in axillary buds in the mid or bottom portions of canes and during subsequent stages of organogenesis the buds in basal and distal sections lagged behind those buds in the midsection. Comparing buds in a similar section of main and basal branch canes, buds on the main canes were more advanced than those buds on basal branch canes in 'Boysen' and 'Marion' (Tables 2 and 3).

As rapidly growing branch canes may suppress branches that are in a more proximal position as a result of apical dominance, buds in the midsection that are already initiated may retard the production of further flowers in buds at nodes proximal to the main cane. The results of this study indicate that almost all buds along the branch canes of 'Cherokee' blackberry are capable of making transition to reproductive buds, but there are conditions that retard or prevent the full expression of flower bud development in all axillary buds. Perhaps flower bud development at the basal nodes is limited by carbohydrate supply or exposure to low irradiance levels. We observed that buds at the basal three nodes were somewhat smaller than those buds in the midsection and, in some cases, lacked a subtending leaf. Typically, the green tips on untrimmed branches are killed after autumn frost or by excess desiccation in winter.

In this study, we were unable to determine precisely at which node flower buds were first initiated, but were, however, able to determine that the buds located in the midsection or lower section of $3 \mathrm{~m}$ or longer canes of trailing 'Boysen' and 'Marion' blackberries were more advanced than the buds located at the terminal one-third section (Tables 2 and 3). We also established that development remained more advanced in the region where it started in all three cultivars. Examination of buds on the untrimmed 'Cherokee' branch canes also indicated that buds in the mid section were more advanced than the buds located either most proximal or distal to the main cane (Fig. 1). Robertson (1957) described the initiation of flower buds in red raspberry as beginning in axillary buds five to ten nodes below the apex of the cane and proceeding progressively towards the bottom of the cane. We concluded that flower bud development in blackberry does not occur in a basipetal fashion on main or branch canes, rather it begins in the mid section of canes and proceeds toward the basal and terminal nodes. The differences in the direction of bud development in red raspberry and blackberry could be that the raspberry canes are upright while the branches of blackberries examined in this study were generally oriented horizontally. Also, trailing blackberry canes and branch canes of erect blackberries commonly grow through October in the Pacific Northwest and elsewhere. These canes do not develop a distinct terminal bud. Also, the stem tissue in terminal portions is less mature than the middle or basal portions. As a result, buds in the terminal portions of these canes are not as advanced in flower bud development as buds in the middle or basal portions of canes.

More research is needed to document the extent of variation that occurs in the timing of flower bud developmental events within individual branches and among branches as well as plants of a given blackberry cultivar at a specific location, and to determine the effect of cane orientation (i.e., upright, horizontal, and downward) on bud development. A clearer understanding of stages of bud development and differentiation in blackberries will be of value for interpreting experiments on primocane management, canopy manipulation, or analysis of the effects of temperature or photoperiod on cane development and subsequent fruit production.

\section{Literature Cited}

Bernier, G., J. Kinet, and R.M. Sachs. 1981. The physiology of flowering. II. Transition to reproductive growth. CRC Press, Boca Raton, Fla.

Carew, J.G., T. Gillespie, J. White, H. Wainwright, R. Brennan, and N.H. Battey. 2000. The control of the annual growth cycle in raspberry. J. Hort. Sci. Biotechnol. 75:495-503.

Crandall, P.C. 1995. Bramble production: The management and marketing of raspberries and blackberries. Food Products Press, Binghamton, N.Y.

Crandall, P.C. and J.D. Chamberlain. 1972. Effects of water stress, cane size, and growth regulators on floral primordia development in red raspberries. J. Amer. Soc. Hort. Sci. 97:418-419.

Dunn, O.J. 1964. Multiple comparisons using rank sums. Technometrics 6:241252.

Lamp, B.M., J.H. Connell, R.A. Duncan, M. Viveros, and V.S. Polito. 2001. Almond flower development: Floral initiation and organogenesis. J. Amer. Soc. Hort. Sci. 126:689-696.

Moore, J.N. and J.D. Caldwell. 1985. Rubus, p. 226-238. In: A.H. Halevy (ed.). CRC handbook of flowering. vol. 4. CRC Press, Boca Raton, Fla.

Moore, J.N. and R.M. Skirvin. 1990. Blackberry management, p. 214-244. In: G.J. Galletta and D.C. Himelrick (eds.). Small fruit crop management. Prentice-Hall Press, Englewood, N.J.

Patterson, W.K. 1992. Blackberry production in Arkansas. Univ. Ark. Coop. Ext. Fact Sheet A2082.

Robertson, M. 1957. Further investigation of flower-bud development in the genus Rubus. J. Hort. Sci. 32:265-273.

Stanley, C.J., P.M. Harris-Virgin, C.G.T. Morgan, and A.M. Snowball. 1999. Boysenberry primocane management for improved productivity. Acta Hort. 505:79-86.

Strik, B. 1992. Blackberry cultivars and production trends in the Pacific Northwest. Fruit Var. J. 46:202-206.

Takeda, F. and D.L. Peterson. 1999. Considerations for machine harvesting freshmarket eastern thornless blackberries: Trellis designs, cane training systems, and mechanical harvester developments. HortTechnology 9:16-21.

Takeda, F., B.C. Strik, D. Peacock, and J.R. Clark. 2002. Cultivar differences and the effect of winter temperature on flower bud development in blackberry. J. Amer. Soc. Hort. Sci. 127:495-501.

Takeda, F. and M. Wisniewski. 1989. Organogenesis and patterns of floral bud development in two eastern thornless blackberry cultivars. J. Amer. Soc. Hort. Sci. 114:528-531.

Waldo, G.F. 1933. Fruit bud formation in brambles. Proc. Amer. Soc. Hort. Sci. 30:263-267.

Warmund, M.R. and M.F. George. 1990. Freezing survival and supercooling in primary and secondary buds of Rubus spp. Can. J. Plant Sci. 70:893-904.

Warmund, M.R., M.F. George, and B.G. Cumbie. 1988. Supercooling in 'Darrow' blackberry buds. J. Amer. Soc. Hort. Sci. 113:418-422.

Warmund, M.R., F. Takeda, and G.A. Davis. 1992. Supercooling and extracellular ice formation in differentiating buds of eastern thornless blackberry. J. Amer. Soc. Hort. Sci. 117:941-945.

Williams, I.H. 1959. Effects of environment on Rubus idaeus L.: IV. Flower initiation and development of the inflorescence. J. Hort. Sci. 34:219-228. 